OPEN ACCESS

Edited by:

Antonio La Marca,

University of Modena and Reggio

Emilia, Italy

Reviewed by:

Fulvio Zullo,

University of Naples Federico II, Italy

Bulent Urman,

Koç University, Turkey

*Correspondence:

Nikolaos P. Polyzos

nikpol@dexeus.com

Specialty section: This article was submitted to

Reproduction,

a section of the journal

Frontiers in Endocrinology

Received: 15 January 2021 Accepted: 23 April 2021

Published: 17 May 2021

Citation:

Neves AR, Montoya-Botero $P$ and

Polyzos NP (2021) The Role of

Androgen Supplementation in Women With Diminished Ovarian Reserve: Time

to Randomize, Not Meta-Analyze.

Front. Endocrinol. 12:653857.

doi: 10.3389/fendo.2021.653857

\section{The Role of Androgen} Supplementation in Women With Diminished Ovarian Reserve: Time to Randomize, Not Meta-Analyze

\author{
Ana Raquel Neves ${ }^{1,2}$, Pedro Montoya-Botero ${ }^{3}$ and Nikolaos P. Polyzos ${ }^{1,4 *}$ \\ 1 Department of Obstetrics, Gynecology and Reproductive Medicine, Dexeus University Hospital, Barcelona, Spain, 2 Faculty \\ of Medicine, Autonomous University of Barcelona, Cerdanyola del Vallès, Spain, ${ }^{3}$ Department of Reproductive Medicine, \\ Conceptum - Unidad de Fertilidad del Country, Bogotá, Colombia, ${ }^{4}$ Faculty of Medicine and Health Sciences, Ghent \\ University (UZ Gent), Gent, Belgium
}

The management of patients with diminished ovarian reserve (DOR) remains one of the most challenging tasks in IVF clinical practice. Despite the promising results obtained from animal studies regarding the importance of androgens on folliculogenesis, the evidence obtained from clinical studies remains inconclusive. This is mainly due to the lack of an evidence-based methodology applied in the available trials and to the heterogeneity in the inclusion criteria and IVF treatment protocols. In this review, we analyze the available evidence obtained from animal studies and highlight the pitfalls from the clinical studies that prevent us from closing the chapter of this line of research.

Keywords: androgens, testosterone, DHEA, poor ovarian response (POR), diminished ovarian response (DOR)

\section{INTRODUCTION}

In women, testosterone and dihydrotestosterone (DHT), the bioactive androgens that bind directly to the androgen receptor (AR), are produced by peripheral conversion of androgen precursors (androstenedione, dehydroepiandrosterone and dehydroepiandrosterone sulfate) that are secreted from both the ovary and adrenal gland $(1,2)$.

The AR is expressed at all levels of the female hypothalamic-pituitary-gonadal axis (2). In the ovary, the AR has been detected in several stages of oocyte development from the primary stage onwards, as well as in the ovarian stroma (3). The fact that hyperandrogenic women present an increased number of small antral follicles suggests a role for androgens in both follicular development and follicular arrest. Clinical examples of this effect include polycystic ovarian syndrome (PCOS) and congenital adrenal hyperplasia patients (4). On the other hand, although initial studies using histomorphologic criteria suggested that exposure to exogenous testosterone treatment in female-to-male transexual patients induced polycystic ovary morphology $(5,6)$, more recent studies using both histologic and ultrasound criteria have not confirmed these findings (7-9).

Circulating androgen levels have been reported to decline with age, especially during the earlier reproductive years (10). Similarly, the reproductive aging process consists of a gradual reduction in oocyte quantity and quality, with a consequent age-related decrease in the reproductive potential $(11,12)$. In the light of these findings, IVF centers have initiated androgen pretreatment in patients with diminished ovarian reserve, intending to improve their reproductive outcomes. In fact, a recent 
survey has shown that more than $40 \%$ of physicians in Europe and Australia are prescribing off-label androgens in this subgroup of patients (13). However, the evidence for including this approach in our clinical practice is scarce.

The aim of this review is to analyze the available evidence from animal studies regarding the impact of androgen supplementation on folliculogenesis, as well as the drawbacks from clinical studies that might preclude the obtention of definitive conclusions to guide an evidence-based approach for such a challenging population.

\section{METHODS}

The Cochrane Central Register of Controlled Trials (CENTRAL), MEDLINE via PubMed, the Web of Science and Scopus were screened with a combination of keywords related to ART, poor responders, diminished ovarian response, androgens, testosterone and DHEA in various combinations. The search period was from the date of inception of each database until 1 December 2020. Only full text papers published in English were included.

\section{THE PROMISING EVIDENCE FROM ANIMAL STUDIES}

\section{Primordial Follicle Initiation}

Previous studies in primates have shown that androgens increase the numbers of small- and medium-sized follicles but not large preovulatory follicles (14). In particular, testosterone and DHT pretreatment increased the number of primary follicles. Also, they resulted in a significant increase in insulin growth factor I (IGF-I) and IGF-I receptor mRNAs in the oocytes of primordial follicles, suggesting that androgen-induced activation of oocyte IGF-I signaling may trigger primordial follicle growth (15). More recently, mouse studies have corroborated that testosterone promotes primordial follicle to primary follicle transition via an AR-mediated pathway rather than by transformation into estradiol (16).

\section{Preantral to Antral Stage Transition}

Besides the effect on primordial follicle initiation, androgens also seem to have a role in the preantral to antral stage transition. In vivo studies in ovine models have shown that DHEA exposure stimulates early follicular growth during the preantral and early antral follicular stages (17). Studies in mouse models have also shown that both DHT and testosterone stimulate granulosa cell (GC) proliferation and both secondary and preantral follicle growth (18). Moreover, androgens seem to support follicle development during the FSH-dependent preantral stage by increasing the expression of FSH receptor mRNA levels and, therefore, enhancing FSH action (19, 20). GC-specific AR-null mice experiments have also shown that AR signaling in GCs is necessary for progression beyond the preantral stage (21). Androgens enhance antiapoptotic pathways, thereby contributing to follicle survival, and improve sensitivity to FSH-induced follicle growth and progression to the antral stage (22). On the other hand, when AR signaling is blocked, preantral follicles cannot progress to antral follicles and, instead, are subjected to an increased rate of atresia.

\section{The Peri-Ovulatory Stage}

The effect of androgens in later stages of follicle development, namely in the pre- and peri-ovulatory stage, is controversial. Studies in primates have shown that testosterone treatment did not increase the number of preovulatory follicles (14). However, experiments in pigs have shown that androgens might have regulatory functions during late follicular development (23). In fact, DHT treatment resulted in an increase in the amount of FSH receptor mRNA in preovulatory follicles and increased ovulation rate (23). Similarly, experiments in mice have also shown that testosterone has a role in the maturation of oocytes arrested in prophase I of meiosis (24) and that DHT significantly increased the number of ovulated oocytes (22). On the other hand, Romero and Smitz reported that elevated levels of androstenedione and testosterone negatively affected meiotic resumption (25). These conflicting findings regarding the role of androgens in the late stages of follicular development suggest that further studies are needed to clarify the physiopathology behind such complex interactions.

Figure 1 highlights the main androgen effects on folliculogenesis.

\section{Genetic Studies}

Finally, data from genetic models have also reaffirmed the role of AR-mediated activity in the regulation of ovarian function. Studies using female mouse models homozygous for an inactivated AR (ARKO) have revealed reduced fertility and a defective folliculogenesis (26-28), as well as a reduced litter size (27), increased follicular atresia and premature ovarian failure (21). Together, these data suggest the AR signaling pathway mediates both intra and extra-ovarian actions, with an essential role in maintaining normal ovarian function and fertility.

\section{THE PITFALLS FROM CLINICAL STUDIES}

All these promising data obtained from animal studies and the fact that both androgens and ovarian reserve decline steeply with age, led to the speculation that androgen replacement in women with DOR might delay these age-related effects. However, despite several lines of evidence supporting a role for androgens in folliculogenesis, the available data from clinical studies remains unconvincing. This might be related to the methodological inconsistencies observed in the available trials (Tables $\mathbf{1}$ and 2).

\section{Dehydroepiandrosterone}

A case series of five patients with unexplained infertility and previous poor response to ovarian stimulation was the first study to analyze the effect of DHEA pretreatment on ovarian response (51). In this study, $80 \mathrm{mg} /$ day of oral micronized DHEA was given for 2 months, after which ovarian stimulation was started 


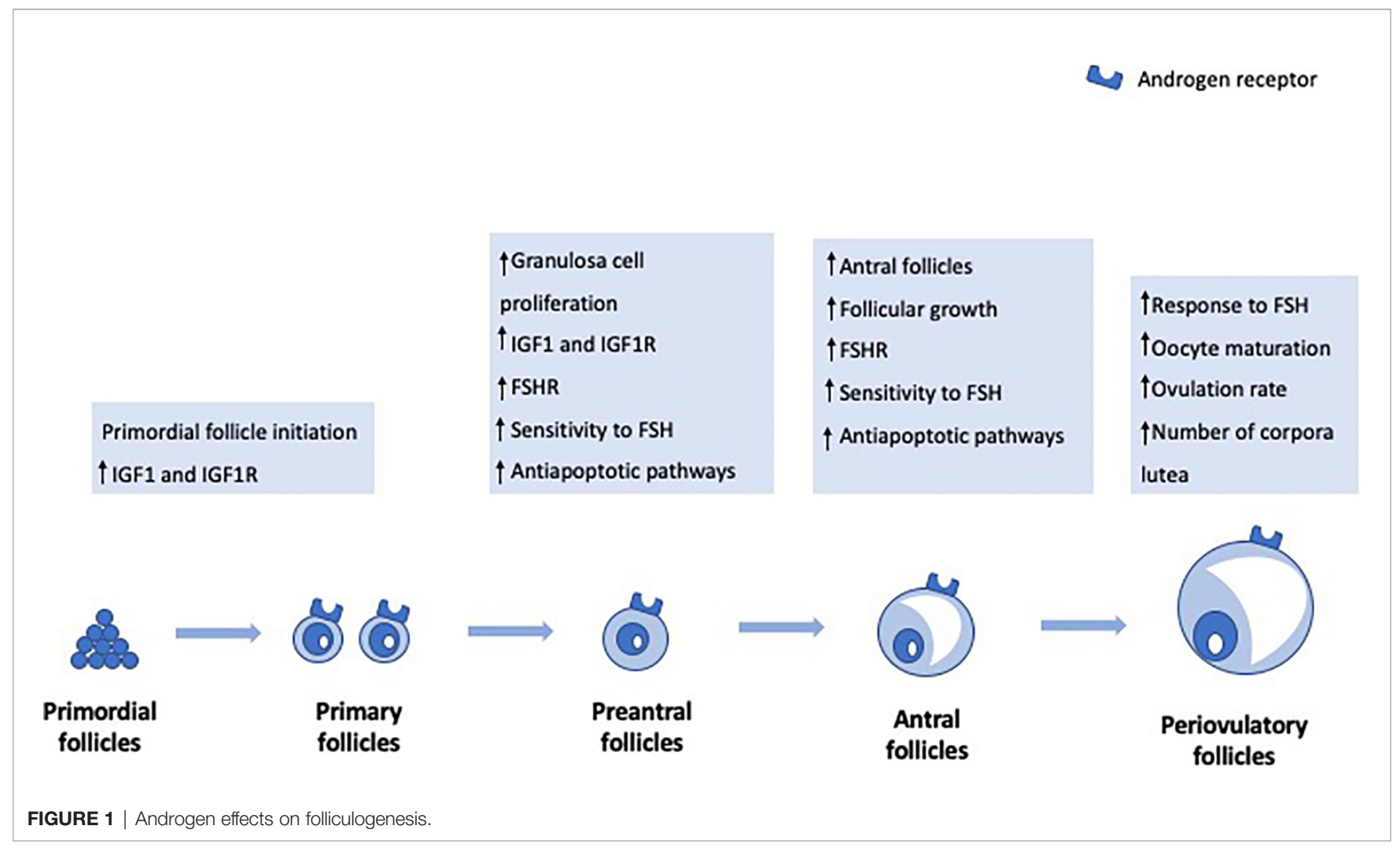

with recombinant follicle stimulating hormone ( $\mathrm{rFSH}$ ) for intrauterine insemination. The authors concluded that oral DHEA supplementation might improve ovarian response and reduce gonadotrophin consumption. Five years later, a case report of a 43-years old patient seeking embryo accumulation for preimplantation genetic screening draw the scientific community's attention to the role of androgens in ovarian response to stimulation (52). After her first stimulation cycle, the patient started self-administering $75 \mathrm{mg} /$ day of oral micronized DHEA and initiated acupuncture treatment. In total, the patient performed 9 stimulation cycles with different stimulation protocols, and a significant increase in ovarian response was reported after four months of DHEA pretreatment. Since then, multiple observational and randomized controlled trials have followed, with varying DOR and poor ovarian reserve (POR) definitions, with DHEA doses ranging from 50 to $90 \mathrm{mg} /$ day and a treatment duration ranging from 1 to 12 months, both before and during controlled ovarian stimulation (Tables 1 and 2). Importantly, no pharmacological studies have been performed to determine the optimal dose, duration or timing of DHEA supplementation in DOR patients.

Another key limitation regarding many studies on DHEA pre-treatment is the frequent use of patients as their own controls, comparing ovarian response after DHEA supplementation with a previous cycle. This study design does not take into account the importance of biological variability in the response to ovarian stimulation and the natural process of the regression to the mean, precluding definitive conclusions regarding the true effect of such treatment (77).
Also noteworthy is the fact that oral DHEA formulations are dietary supplements and therefore are not regulated by the US Food and Drug Administration (FDA) nor by the European Medicines Agency (EMA) and are exempt from pharmaceutical quality standards. Consequently, the true standardization of the formulations used cannot be guaranteed (78).

\section{Testosterone}

Numerous observational and randomized controlled trials have also been published on the use of testosterone pre-treatment on POR and DOR patients (Tables 1 and 2). Most studies report the use of transdermal testosterone, both in gel and patches, with doses of treatment based on Vendola's studies on primates (14, 15). In these studies, an effect on follicular development was reported with transdermal testosterone $20 \mu \mathrm{g} / \mathrm{Kg} / \mathrm{day}$, obtained with a $12.5 \mathrm{mg} /$ day gel application or a $2.5 \mathrm{mg} /$ day patch. Importantly, however, pharmacokinetics studies performed in postmenopausal women revealed that the administration of 4.4-5 mg testosterone gel or cream raised free testosterone levels within the reference range for reproductive-aged women whereas higher doses increased testosterone levels above the physiological range $(79,80)$. These findings question the potential clinical benefit (or harm) of using the high doses that have been reported so far.

The issue of the duration of treatment has also been another point of conflict in the published studies, ranging from 5 days, based on Vendola's studies $(14,15)$, to $21-28$ days, based on a RCT that reported that testosterone effects at the follicular level occurred after at least three weeks of testosterone pre-treatment (32). 


\section{Testosterone}

Massin et al. (29) 2006 * or E2 $>70 \mathrm{pg} / \mathrm{mL}$ or Inhibin B $<45 \mathrm{ng} / \mathrm{mL}$

Fábregues et al. (30) 2009 Previous POR and 31-39y

Kim et al. (31) 2011

Previous cycle with $\leq 3$ oocytes retrieved despite high Gn dose

Kim et al. (32) 2014
Previous POR (Peak E2 $<1200 \mathrm{pg} / \mathrm{mL}$ and $\leq 5$ oocytes) and D3 FSH $>12 \mathrm{IU} / \mathrm{L}$
Marzal Escrivá et al. (33)

2015

Bosdou et al. (34) 2016

\section{DHEA}

Wiser et al. (36) 2010

Artini et al. (37) 2012

Moawad and Shaeer (38) 2012

Yeung et al. (39) $2013^{*}$

Yeung et al. (40) $2014^{*}$

Kara et al. (41) 2014

Zhang et al. (42) 2014

Kotb et al. (43) 2016 Agarwal et al. (44) 2017

Narkwichean et al. (45) $2017^{*}$
Elprince et al. (46) 2020 *

\begin{tabular}{|c|c|c|c|c|}
\hline 49 & $10 \mathrm{mg} / \mathrm{d}$ & $15-20 d$ & NR & Total number of retrieved oocytes \\
\hline 62 & $20 \mathrm{ug} / \mathrm{kg} / \mathrm{d}$ & $5 d$ & Long GnRH agonist & Incidence of low responders \\
\hline 110 & $12.5 \mathrm{mg} / \mathrm{d}$ & $21 d$ & GnRH antagonist & Number of Mll oocytes retrieved \\
\hline 120 & $12.5 \mathrm{mg} / \mathrm{d}$ & $\begin{array}{l}\text { I1: } 14 \mathrm{~d} / \\
\text { I2: } 21 \mathrm{~d} / \\
\text { I3: } 28 \mathrm{~d}\end{array}$ & GnRH antagonist & Number of Mll oocytes retrieved \\
\hline 66 & $20 \mathrm{ug} / \mathrm{kg} / \mathrm{d}$ & $7 d$ & $\mathrm{GnRH}$ antagonist & Number of MII oocytes retrieved \\
\hline 50 & $10 \mathrm{mg} / \mathrm{d}$ & $21 d$ & Long GnRH agonist & Total number of retrieved oocytes \\
\hline 48 & $25 \mathrm{mg} / \mathrm{d}$ & During COS & GnRH antagonist & NR \\
\hline 33 & $75 \mathrm{mg} / \mathrm{d}$ & $>6$ weeks & Long GnRH agonist & $\begin{array}{l}\text { Peak estradiol levels, the number of } \\
\text { retrieved oocytes, embryo quality and } \\
\text { number of embryos reserved for transfer }\end{array}$ \\
\hline 24 & $75 \mathrm{mg} / \mathrm{d}$ & 12 weeks & GnRH antagonist & $\begin{array}{l}\text { HIF1 and VEGF concentrations in the FF } \\
\text { and the number of Mll oocytes }\end{array}$ \\
\hline 133 & $75 \mathrm{mg} / \mathrm{d}$ & $>12$ weeks & GnRH antagonist & $\begin{array}{l}\text { Peak E2 levels, number of retrieved } \\
\text { oocytes and number of embryos }\end{array}$ \\
\hline 22 & $75 \mathrm{mg} / \mathrm{d}$ & 16 weeks & NA & Serum AMH level \\
\hline 32 & $75 \mathrm{mg} / \mathrm{d}$ & 12 weeks & $\mathrm{GnRH}$ antagonist & $\begin{array}{l}\text { The primary outcome was the AFC at } 12 \\
\text { weeks }\end{array}$ \\
\hline 208 & $75 \mathrm{mg} / \mathrm{d}$ & 12 weeks & Microdose flare & NR \\
\hline 95 & $75 \mathrm{mg} / \mathrm{d}$ & 12 weeks & $\begin{array}{l}\mathrm{HMG}+\text { Clomiphene } \\
\text { citrate }\end{array}$ & $\begin{array}{l}\text { Follicular fluid BMP- } 15 \text { and GDF-9 and } \\
\text { serum AMH, FSH and E2 }\end{array}$ \\
\hline 140 & $75 \mathrm{mg} / \mathrm{d}$ & 3 months & GnRH antagonist & Clinical pregnancy rate \\
\hline 40 & $75 \mathrm{mg} / \mathrm{d}$ & 12 weeks & NA & $\mathrm{AMH}, \mathrm{FSH}$ and $\mathrm{AFC}$ \\
\hline 52 & $75 \mathrm{mg} / \mathrm{d}$ & $>12$ weeks & Long GnRH agonist & Number of oocytes retrieved \\
\hline 50 & $75 \mathrm{mg} / \mathrm{d}$ & $\begin{array}{c}2 \\
\text { Continuous } \\
\text { cycles }\end{array}$ & Ovulation induction & NR \\
\hline
\end{tabular}

$\geq 2$ : $\geq 38 \mathrm{y}$, AFC $\leq 6, F S H \geq 10 \mathrm{IU} / \mathrm{L}, \mathrm{AMH} \leq 5 \mathrm{pg} / \mathrm{mL}$ AND $\leq 4$ follicles of $\geq 16 \mathrm{~mm}$ on the day of trigger or $E 2 \leq 500 \mathrm{pg} / \mathrm{mL}$ on the day of trigger or $\leq 4 \mathrm{Ml}$

Bologna criteria

Bologna criteria

$<5$ oocytes retrieved in previous cycle; poor quality embryos; previous cycle cancelation due to poor response with rFSH $300 \mathrm{IU}$

\section{Bologna criteria}

$<40 y ;<5$ oocytes retrieved in previous cycle; previous cycle cancelation due to poor response with $\mathrm{rFSH} 300 \mathrm{IU}$; $\mathrm{AMH}<1.7 \mathrm{ng} / \mathrm{mL}$

$<40 \mathrm{y}$, subfertility $>1 \mathrm{y}$ and $\mathrm{AFC}<5$

D3 FSH $\geq 1$ OlU/L or FSH/LH $>3$; AFC $<5$; previous cycle with $<5$ oocytes retrieved or previous cancelled cycle due to $\mathrm{POR}$

Bologna criteria 25-40y

18-45y with DOR: (1) FSH levels $>7 \mathrm{mlU} / \mathrm{ml}$ for age $<33 \mathrm{y}$; $>7.9 \mathrm{mlU} / \mathrm{ml}$ for age 33-37y; $>8.4 \mathrm{mlU} / \mathrm{ml}$ for age $>38$ years. (2) $\mathrm{AMH}<1.05 \mathrm{ng} / \mathrm{ml}$. (3) $\mathrm{AFC}<4$ $\mathrm{AFC}<10$ and/or $\mathrm{AMH}<5 \mathrm{pmol} / \mathrm{L}$

(1) serum $A M H<1.1 \mathrm{ng} / \mathrm{mL}$, (2) $F S H \geq 10 \mathrm{mlU} / \mathrm{L}$ and $\leq 15 \mathrm{mlU} / \mathrm{L}$ on cycle D3, and (3) $\mathrm{AFC} \leq 4$
$\mathrm{AMH}<1 \mathrm{ng} / \mathrm{mL}$ or $\mathrm{FSH}>15 \mathrm{IU} / \mathrm{L}$ and $\mathrm{AFC}<4$

* Placebo controlled.

AFC, antral follicle count; AMH, antimullerian hormone; BMP-15, bone morphogenetic protein-15; d, day(s); E2, estradiol; FF, follicular fluid; FSH, follicle stimulating hormone; GDF-9, growth differentiation factor-9; Gn, gonadotropin; GnRH, gonadotropin releasing hormone; HIF, Hypoxia inducible factor; MII, mature oocytes; NR, not reported; NA, not applicable; POI, premature ovarian insufficiency; POR, poor ovarian responders; VEGF, vascular endothelial growth factor; $y$, years. 


\begin{tabular}{|c|c|c|c|c|c|c|c|}
\hline Author Year & Study design & Definition of POR & $\begin{array}{c}\text { Number } \\
\text { of } \\
\text { patients }\end{array}$ & Dose & Duration & $\begin{array}{l}\text { Stimulation } \\
\text { protocol }\end{array}$ & Main outcome measure \\
\hline \multicolumn{8}{|l|}{ Testosterone } \\
\hline Balasch et al. (47) 2006 & $\begin{array}{l}\text { Prospective } \\
\text { self-controlled }\end{array}$ & $\begin{array}{l}\text { 31-39y patients undergoing their third IVF } \\
\text { attempt with } 1 \text { or } 2 \text { previous IVF cycles } \\
\text { cancelled because of poor follicular } \\
\text { response, with basal FSH }<10 \text { IUU/L }\end{array}$ & 25 & $\begin{array}{l}2.5 \mathrm{mg} / \mathrm{d} \\
\text { Patch }\end{array}$ & $5 d$ & Long GnRH agonist & NR \\
\hline Mitri et al. (48) 2016 & Retrospective & $\begin{array}{l}\text { At least one previous failed or cancelled } \\
\text { IVF cycle with suspected Gn resistance } \\
\text { (serum FSH } \geq 20 \mathrm{mIU} / \mathrm{L} \text { on D7) and } \\
\text { absent or minimal follicular growth during } \\
\text { the current cycle. }\end{array}$ & 26 & $25 \mathrm{mg} / \mathrm{d}$ gel & variable & $\begin{array}{l}\text { Microflare GnRH } \\
\text { agonist with } \\
\text { interrupted FSH }\end{array}$ & NR \\
\hline Doan et al. (49) 2017 & Prospective & $\begin{array}{l}\text { History or probability of POR: AFC }<5-7 \text { or } \\
\mathrm{AMH} \leq 1.26 \mathrm{ng} / \mathrm{ml})\end{array}$ & 110 & $12.5 \mathrm{mg} / \mathrm{d}$ gel & $28 d$ & GnRH antagonist & NR \\
\hline Fabregues et al. (50) 2019 & Retrospective & Bologna criteria & 141 & $2.5 \mathrm{mg} / \mathrm{d}$ Patch & $5 d$ & $\begin{array}{l}\text { GnRH antagonist } \\
\text { and Long GnRH } \\
\text { agonist }\end{array}$ & $N R$ \\
\hline \multicolumn{8}{|l|}{ DHEA } \\
\hline Casson et al. (51) 2000 & Case series & $\begin{array}{l}\text { Previous POR to vigorous Gn stimulation } \\
\text { (peak estradiol } \leq 500 \mathrm{pg} / \mathrm{ml}, \mathrm{MIl} \leq 2 \text { ) }\end{array}$ & 5 & $80 \mathrm{mg} / \mathrm{d}$ & 2 months & Ovulation induction & $N R$ \\
\hline Barad and Gleicher (52) 2005 & Case report & 43y patient & 1 & $75 \mathrm{mg} / \mathrm{d}$ & 11 months & GnRH agonist & $\begin{array}{l}\text { Peak E2 concentration, oocytes retrieved, and } \\
\text { cyropreservable embryos. }\end{array}$ \\
\hline Barad and Gleicher (53) 2006 & $\begin{array}{l}\text { Retrospective } \\
\text { self-controlled }\end{array}$ & $\begin{array}{l}\text { Prior IVF cycle with age-appropriate COS, } \\
\text { and }<4 \text { oocytes retrieved, uniformly poor } \\
\text { embryo quality and } \mathrm{FSH}>10 \mathrm{mlU} / \mathrm{ml} \text { or } \\
\text { E2 }>75 \mathrm{pg} / \mathrm{ml}\end{array}$ & 25 & $75 \mathrm{mg} / \mathrm{d}$ & $\begin{array}{l}17.6 \pm 2.13 \\
\text { weeks }\end{array}$ & GnRH agonist & $\mathrm{NR}$ \\
\hline Barad et al. (54) 2007 & Retrospective & $\begin{array}{l}\text { Basal FSH }<12 \mathrm{mlU} / \mathrm{ml} \text {, but exceeding the } \\
95 \% \mathrm{Cl} \text { of the mean value for the patient's } \\
\text { age group or vasal } \mathrm{FSH} \geq 12 \mathrm{mlU} / \mathrm{ml} \text { and } \\
\text { or a baseline estradiol level } \geq 75 \mathrm{pg} / \mathrm{ml}\end{array}$ & 190 & $75 \mathrm{mg} / \mathrm{d}$ & $\begin{array}{l}3.8 \pm 0.3 \\
\text { months }\end{array}$ & $\begin{array}{l}\text { Microflare GnRH } \\
\text { agonist }\end{array}$ & Clinical pregnancy rate \\
\hline $\begin{array}{l}\text { Mamas and Mamas (55) } \\
2009\end{array}$ & Case series & $\mathrm{POI}$ & 5 & $50-75 \mathrm{mg} / \mathrm{d}$ & 2-6 months & NA & NR \\
\hline $\begin{array}{l}\text { Mamas and Mamas (56) } \\
2009\end{array}$ & Case series & $\mathrm{POI}$ & 14 & $50-75 \mathrm{mg} / \mathrm{d}$ & 3-7 months & NA & NR \\
\hline Sonmezer et al. (57) 2009 & $\begin{array}{l}\text { Prospective } \\
\text { self-controlled }\end{array}$ & $\begin{array}{l}\text { (i) cycle cancellation due to } \mathrm{E} 2<130 \mathrm{pg} / \mathrm{ml} \\
\text { on cycle } \mathrm{D} 6 \text { or }<450 \mathrm{pg} / \mathrm{ml} \text { on the day of } \\
\text { trigger, (ii) }<4 \text { retrieved oocytes despite } \\
\text { vigorous ovarian stimulation. }\end{array}$ & 19 & $75 \mathrm{mg} / \mathrm{d}$ & $90-180 d$ & GnRH antagonist & $\begin{array}{l}\text { Antral follicle count, number of follicles }>14 \text { and } \\
>17 \mathrm{~mm} \text { on the day of HCG administration, E2 on } \\
\text { the day of HCG administration, number of retrieved } \\
\text { oocytes, mean number of MII, number of transferred } \\
\text { embryos and rates of fertilization, implantation, } \\
\text { pregnancy, and clinical pregnancy. }\end{array}$ \\
\hline Gleicher et al. (58) 2009 & Retrospective & $\begin{array}{l}\text { Definition of POR changed over the study } \\
\text { period }\end{array}$ & 73 & $75 \mathrm{mg} / \mathrm{d}$ & $>2$ months & $N R$ & Miscarriage rate \\
\hline Gleicher et al. (59) 2010 & Retrospective & $\begin{array}{l}\text { Elevated age-specific baseline FSH or } \\
\text { abnormally low age-specific AMH }\end{array}$ & 66 & $75 \mathrm{mg} / \mathrm{d}$ & $>4$ weeks & $\begin{array}{l}\text { Microflare GnRH } \\
\text { agonist }\end{array}$ & Number and percentage of aneuploid embryos \\
\hline Gleicher et al. (60) 2010 & Retrospective & $\begin{array}{l}\text { Elevated age-specific baseline FSH or } \\
\text { universal } \mathrm{AMH}<0.8 \mathrm{ng} / \mathrm{ml}\end{array}$ & 120 & $75 \mathrm{mg} / \mathrm{d}$ & $73 \pm 27 d$ & NA & $\mathrm{AMH}$ \\
\hline
\end{tabular}




\begin{tabular}{|c|c|c|c|c|c|c|c|}
\hline Author Year & Study design & Definition of POR & $\begin{array}{c}\text { Number } \\
\text { of } \\
\text { patients }\end{array}$ & Dose & Duration & $\begin{array}{l}\text { Stimulation } \\
\text { protocol }\end{array}$ & Main outcome measure \\
\hline Weissman et al. (61) 2011 & $\begin{array}{l}\text { Retrospective } \\
\text { self-controlled }\end{array}$ & $\begin{array}{l}>1 \text { of the following characteristics in a } \\
\text { previous cycle with high-dose } \mathrm{Gn} \\
\text { stimulation: }<5 \text { oocytes retrieved, } \leq 3 \\
\text { follicles } \geq 16 \mathrm{~mm} \text { on the day of cycle } \\
\text { cancelation, or E2 level }<500 \mathrm{pg} / \mathrm{ml} \text { on the } \\
\text { day of trigger }\end{array}$ & 15 & $75 \mathrm{mg} / \mathrm{d}$ & $\sim 3$ months & NR & $\begin{array}{l}\text { Progesterone concentration on day } 5 \text { of stimulation } \\
\text { and on the day of } h C G \text { administration. }\end{array}$ \\
\hline Fusi et al. (62) 2013 & Prospective & $\begin{array}{l}\text { Cohort 1: Previous IVF cycle with POR } \\
\text { Cohort 2: }>40 y \text { and DOR (AFC }<4 \text {, FSH } \\
>10 \mathrm{IU} / \mathrm{ml}, \mathrm{AMH}<1 \mathrm{ng} / \mathrm{ml}\end{array}$ & 101 & $75 \mathrm{mg} / \mathrm{d}$ & $>3$ months & Long GnRH agonist & Spontaneous pregnancies \\
\hline Hyman et al. (63) 2013 & $\begin{array}{l}\text { Prospective } \\
\text { self-controlled }\end{array}$ & $\begin{array}{l}\text { At least one previous IVF cycle with } \leq 4 \\
\text { oocytes retrieved despite high dose Gn } \\
(\geq 450 \text { IU/day) }\end{array}$ & 43 & $75 \mathrm{mg} / \mathrm{d}$ & $>3$ months & NR & NR \\
\hline Singh et al. (64) 2013 & $\begin{array}{l}\text { Prospective } \\
\text { self-controlled }\end{array}$ & $\begin{array}{l}\text { Poor ovarian response in the previous IVF } \\
\text { cycle(s) }\end{array}$ & 31 & $75 \mathrm{mg} / \mathrm{d}$ & 4 months & NR & $\mathrm{AMH}, \mathrm{FSH}$ and antral follicle count \\
\hline Yilmaz et al. (65) 2013 & Prospective & $\begin{array}{l}\text { AFC }<5 \text { or } \mathrm{AMH}<1.1 \mathrm{ng} / \mathrm{ml} \text { and a } \\
\text { previous poor ovarian response }\end{array}$ & 41 & $75 \mathrm{mg} / \mathrm{d}$ & $>6$ weeks & $\mathrm{GnRH}$ antagonist & AMH, Inhibin B and antral follicle count \\
\hline Jirge et al. (66) 2014 & $\begin{array}{l}\text { Prospective } \\
\text { self-controlled }\end{array}$ & $\begin{array}{l}\text { Bologna criteria < } 40 y \text { s with } 1 \text { previously } \\
\text { failed IVF cycle }\end{array}$ & 31 & $75 \mathrm{mg} / \mathrm{d}$ & $>2$ months & $\mathrm{GnRH}$ antagonist & $\begin{array}{l}\text { Dose and duration of gonadotropin therapy, oocyte } \\
\text { yield, embryo number and quality, pregnancy and live } \\
\text { birth rate. }\end{array}$ \\
\hline Xu et al. (67) 2014 & Retrospective & Bologna criteria & 386 & $75 \mathrm{mg} / \mathrm{d}$ & $90 \mathrm{~d}$ & $\mathrm{GnRH}$ antagonist & Ongoing pregnancy rate and implantation rate \\
\hline Zangmo et al. (68) 2014 & $\begin{array}{l}\text { Prospective } \\
\text { self-controlled }\end{array}$ & $\begin{array}{l}<42 \text { years, with }<5 \text { oocytes retrieved in } \\
\text { previous IVF cycles, D2 FSH } 10-20 \text { mlU/ } \\
\text { ml }\end{array}$ & 50 & $75 \mathrm{mg} / \mathrm{d}$ & 4 months & NR & Oocyte and embryo number and quality \\
\hline Tsui et al. (69) 2015 & $\begin{array}{l}\text { Prospective } \\
\text { self-controlled }\end{array}$ & Bologna criteria & 10 & $90 \mathrm{mg} / \mathrm{d}$ & 12.2 weeks & $\mathrm{GnRH}$ antagonist & $\begin{array}{l}\text { Total doses of } \mathrm{rFSH} \text {, days of stimulation, oocytes } \\
\text { retrieved, fertilized oocytes, Day } 3 \text { embryos, and } \\
\text { transferred embryos }\end{array}$ \\
\hline Vlahos et al. (70) 2015 & Prospective & $\begin{array}{l}\text { At least } 2 \text { of the following: }>40 \text { years, D2 } \\
\text { FSH }>9.5 \mathrm{mlU} / \mathrm{ml}, \mathrm{AMH}<2 \mathrm{ng} / \mathrm{ml} \text {, at least } \\
\text { one previous cycle of } \mathrm{COS} \text { with }<3 \\
\text { oocytes retrieved, at least one cancelled } \\
\text { attempt owing to POR and } \mathrm{E} 2<500 \mathrm{pg} / \\
\mathrm{ml} \text { on the day of trigger }\end{array}$ & 161 & $75 \mathrm{mg} / \mathrm{d}$ & $>3$ months & GnRH antagonist & Live birth rate \\
\hline Hu et al. (71) 2017 & Prospective & $\begin{array}{l}<40 \text { years, subfertility }>1 \text { year, and DOR } \\
\text { (two or more items such as FSH } 10-25 \\
\text { IU/L, E2 }>80 \mathrm{pg} / \mathrm{ml}, \text { AMH }<0.5-1.1 \mathrm{ng} / \mathrm{ml} \\
\text { and AFC } \leq 5 \text { on cycle D2-3 }\end{array}$ & 106 & $75 \mathrm{mg} / \mathrm{d}$ & 8 weeks & $\mathrm{GnRH}$ antagonist & NR \\
\hline Chern et al. (72) 2018 & Retrospective & $\begin{array}{l}\text { Bologna criteria or } 2 \text { episodes of a } \\
\text { previous POR after maximal stimulation } \\
\text { alone }\end{array}$ & 151 & $90 \mathrm{mg} / \mathrm{d}$ & 3 months & $\mathrm{GnRH}$ antagonist & $\begin{array}{l}\text { Number of oocytes retrieved and clinical pregnancy } \\
\text { rate }\end{array}$ \\
\hline Al-Turki et al. (73) 2018 & Prospective & $\begin{array}{l}\text { Bologna criteria, } 25-40 y \text { with previously } \\
\text { failed IVF cycle }\end{array}$ & 62 & $50 \mathrm{mg} / \mathrm{d}$ & 3 months & $\mathrm{GnRH}$ antagonist & $\begin{array}{l}\text { Number of oocytes retrieved, fertilization rate, } \\
\text { number of embryos and pregnancy rate }\end{array}$ \\
\hline Wong et al. (74) 2018 & Prospective & $\mathrm{POI}$ & 31 & $75 \mathrm{mg} / \mathrm{d}$ & 12 months & NA & $\mathrm{AMH}$ \\
\hline Chen et al. (75) 2019 & Retrospective & POSEIDON group 4 & 297 & $90 \mathrm{mg} / \mathrm{d}$ & 3 months & GnRH antagonist & Number of oocytes retrieved and MII \\
\hline Ozcil (76) 2020 & Retrospective & $\begin{array}{l}6 \mathrm{POI} \text { and } 28 \mathrm{POR} \text { according to the } \\
\text { Bologna criteria }\end{array}$ & 34 & $50 \mathrm{mg} / \mathrm{d}$ & 5 months & NA & Spontaneous clinical pregnancy rate \\
\hline
\end{tabular}


This should come as no surprise, if we consider that the progression from a primordial follicle to a periovulatory follicle takes approximately 3 months (81).

\section{Too Much Is Not Enough}

The vast bulk of published original studies and meta-analysis on the use of androgens pre-treatment in DOR and POR patients is depicted in Figure 2. One of the limitations in analyzing the effect of these adjuvant strategies in DOR/POR patients is the definition of diminished and poor response itself. In this context, the Poseidon Group introduced the concept of 'low prognosis patients' and highlighted the need for tailored evidence-based clinical algorithms for each of the four proposed risk groups $(82,83)$. Standardizing the inclusion criteria offuture studies based on these risk groups might be a further step in minimizing study heterogeneity.

Despite the above-mentioned methodological limitations and the heterogeneity among the inclusion criteria and treatment protocols, original studies continue to be published in an attempt to optimize the clinical management of such a challenging population. With the same goal, a disproportionate number of meta-analysis has been published, especially when considering the number of original studies. Table 3 describes the meta-analysis published on the use of DHEA and testosterone supplementation in IVF and the study design of the included trials. If we consider the low level of evidence of some of the included study designs, the lack of evidence-based protocols for both DHEA and testosterone supplementation, the heterogeneity in the definition of POR and DOR and the diversity in the IVF protocols used in the different trials, the clinical impact of the conclusions drawn from these meta-analysis might be called into question. In this regard, an individual patient data approach could be of use in increasing the strength of the available evidence.

However, to break this vicious cycle, we are left with the need to write the story of androgens supplementation in patients with

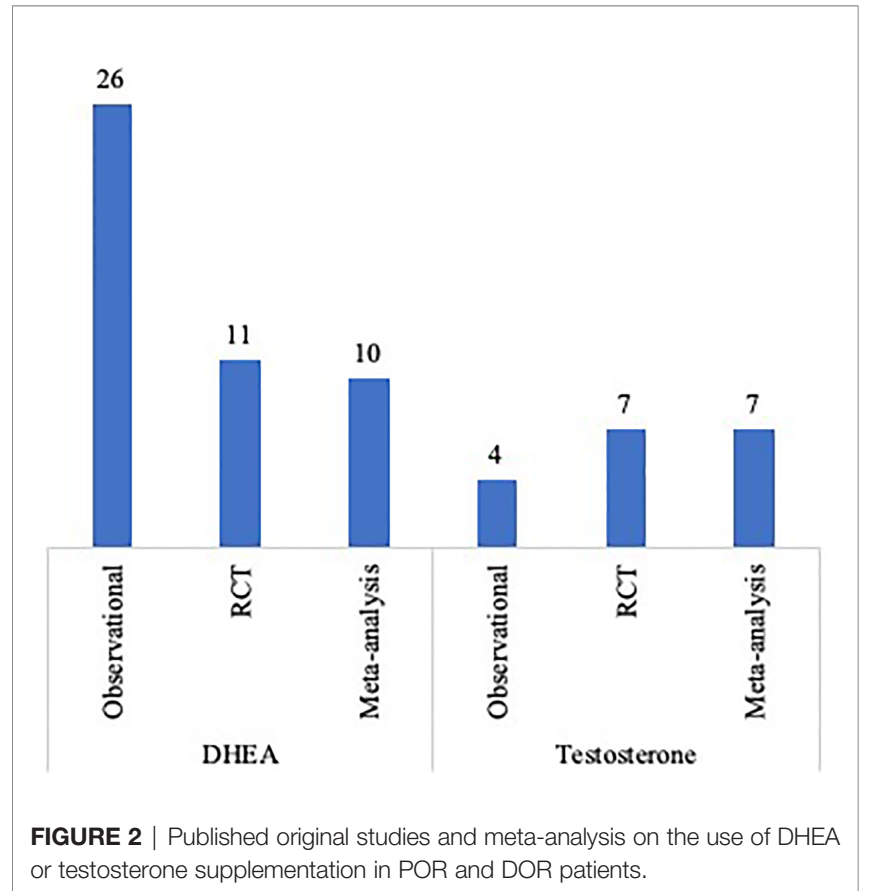

DOR/POR from the beginning. In order to do so, evidence from pharmacokinetics studies (79) as well as from the timespan of human folliculogenesis (97) must be taken into account in what concerns the optimal dose and duration of treatment. In this respect, the currently ongoing multicenter double-blind placebocontrolled randomized controlled trial T-TRANSPORT (NCT02418572, available at http://clinicaltrials.gov/ct2/show/ NCT02418572) might shed some light on this subject. With an intervention group undergoing $5.5 \mathrm{mg}$ daily transdermal testosterone for two months prior to an IVF cycle and powered

TABLE 3 | Published meta-analysis on the use of DHEA and Testosterone in IVF.

\begin{tabular}{|c|c|c|c|c|}
\hline Author & Year & Number of studies & Population & Study design \\
\hline \multicolumn{5}{|l|}{ DHEA } \\
\hline Narckwichean et al. (84) & 2013 & 3 & DOR/POR & $1 \mathrm{RCT}, 2$ Retrospective \\
\hline Li et al. (85) & 2015 & 8 & DOR/POR & $\begin{array}{l}2 \mathrm{RCT}, 2 \text { Prospective, } \\
4 \text { Retrospective }\end{array}$ \\
\hline Qin et al. (86) & 2016 & 9 & DOR/POR & $\begin{array}{l}4 \mathrm{RCT}, 2 \text { Prospective, } \\
3 \text { Retrospective }\end{array}$ \\
\hline Liu et al. (87) & 2017 & 6 & NOR/DOR/POR & $6 \mathrm{RCT}$ \\
\hline Schwarze et al. (88) & 2018 & 5 & DOR/POR & $\begin{array}{l}2 \text { RCT, } 1 \text { Prospective, } \\
2 \text { Retrospective }\end{array}$ \\
\hline Xu et al. (89) & 2019 & 9 & NOR/DOR/POR & $9 \mathrm{RCT}$ \\
\hline \multicolumn{5}{|l|}{ Testosterone } \\
\hline González-Comadran et al. (90) & 2012 & 3 & DOR/POR & $3 \mathrm{RCT}$ \\
\hline Luo et al. (91) & 2014 & 3 & DOR/POR & $3 \mathrm{RCT}$ \\
\hline Noventa et al. (92) & 2019 & 7 & DOR/POR & $7 \mathrm{RCT}$ \\
\hline \multicolumn{5}{|l|}{ Testosterone and DHEA } \\
\hline Sunkara et al. (93) & 2011 & 5 & DOR/POR & $4 \mathrm{RCT}, 1$ Retrospective \\
\hline Bosdou et al. (94) & 2012 & 3 & DOR/POR & $3 \mathrm{RCT}$ \\
\hline Nagels et al. (95) & 2015 & 17 & NOR/DOR/POR/POI & $17 \mathrm{RCT}$ \\
\hline Zhang et al. (96) & 2019 & 4 & POR & $4 \mathrm{RCT}$ \\
\hline
\end{tabular}

DHEA, dehydroepiandrosterone; DOR, diminished ovarian reserve; NOR, normoresponders; POI, premature ovarian insufficiency; POR, poor ovarian responders; RCT, randomized controlled trials. 
with clinical pregnancy rate as the primary outcome measure, this trial is expected to clarify the role of androgens in IVF.

\section{CONCLUSION}

Despite the vast amount of available literature on the use of DHEA and testosterone in POR patients, the bulk of evidence is still limited to draw definite conclusions. More than reviewing the available data and publishing new studies based on the same pitfalls, we urge to restart this chapter with well-designed clinical trials.

\section{REFERENCES}

1. Burger H. Androgen Production in Women. Fertil Steril (2002) 77(Suppl 4): S3-5. doi: 10.1016/S0015-0282(02)02985-0

2. Walters KA, Handelsman DJ. Role of Androgens in the Ovary. Mol Cell Endocrinol (2018) 465:36-47. doi: 10.1016/j.mce.2017.06.026

3. Walters KA. Role of Androgens in Normal and Pathological Ovarian Function. Reproduction (2015) 149(4):R193-218. doi: 10.1530/REP-14-0517

4. Papadakis G, Kandaraki EA, Tseniklidi E, Papalou O, Diamanti-Kandarakis E. Polycystic Ovary Syndrome and NC-CAH: Distinct Characteristics and Common Findings. a Systematic Review. Front Endocrinol (Lausanne) (2019) 10:388. doi: 10.3389/fendo.2019.00388

5. Spinder T, Spijktra JJ, Van Den Tweel JG, Burger CW, Van Kessel H, Hompes PGA, et al. The Effects of Long Term Testosterone Administration on Pulsatile Luteinizing Hormone Secretion and on Ovarian Histology in Eugonadal Female to Male Transsexual Subjects. J Clin Endocrinol Metab (1989) 69(1):151-7. doi: 10.1210/jcem-69-1-151

6. Pache TD, Chadha S, Gooren LJG, Hop WCJ, Jaarsma KW, Dommerholt HBR, et al. Ovarian Morphology in Long-Term Androgen-Treated Female to Male Transsexuals. a Human Model for the Study of Polycystic Ovarian Syndrome? Histopathology (1991) 19(5):445-52. doi: 10.1111/j.1365-2559. 1991.tb00235.x

7. Caanen MR, Schouten NE, Kuijper EAM, Van Rijswijk J, Van Den Berg MH, Van Dulmen-Den Broeder E, et al. Effects of Long-Term Exogenous Testosterone Administration on Ovarian Morphology, Determined by Transvaginal (3D) Ultrasound in Female-to-Male Transsexuals. Hum Reprod (2017) 32(7):1457-64. doi: 10.1093/humrep/dex098

8. Moravek MB, Kinnear HM, George J, Batchelor J, Shikanov A, Padmanabhan $\mathrm{V}$, et al. Impact of Exogenous Testosterone on Reproduction in Transgender Men. Endocrinol (United States) (2020) 161(3):1-13. doi: 10.1210/endocr/ bqaa014

9. Ikeda K, Baba T, Noguchi H, Nagasawa K, Endo T, Kiya T, et al. Excessive Androgen Exposure in Female-to-Male Transsexual Persons of Reproductive Age Induces Hyperplasia of the Ovarian Cortex and Stroma But Not Polycystic Ovary Morphology. Hum Reprod (2013) 28(2):453-61. doi: 10.1093/humrep/des385

10. Davison SL, Bell R, Donath S, Montalto JG, Davis SR. Androgen Levels in Adult Females: Changes With Age, Menopause, and Oophorectomy. J Clin Endocrinol Metab (2005) 90(7):3847-53. doi: 10.1210/jc.2005-0212

11. Broekmans FJ, Soules MR, Fauser BC. Ovarian Aging: Mechanisms and Clinical Consequences. Endocr Rev (2009) 30(5):465-93. doi: 10.1210/ er.2009-0006

12. Alviggi C, Humaidan P, Howles CM, Tredway D, Hillier SG. Biological Versus Chronological Ovarian Age: Implications for Assisted Reproductive Technology. Reprod Biol Endocrinol (2009) 7:101. doi: 10.1186/1477-78277-101

13. Andersen M, Drakopoulos P, Humaidan P, Gomez J, Bruna I, Rombauts L, et al. Off-Label Use of Androgens and Letrozole in Infertile Women - a Multinational Survey in Europe and Australia. Hum Reprod (2018) 33:499.

14. Vendola KA, Zhou J, Adesanya OO, Weil SJ, Bondy CA. Androgens Stimulate Early Stages of Follicular Growth in the Primate Ovary. J Clin Invest (1998) 101(12):2622-9. doi: 10.1172/JCI2081

\section{AUTHOR CONTRIBUTIONS}

AN designed the study, performed the literature review, contributed to the interpretation of the findings, wrote the manuscript and critically revised it. PM-B contributed to the interpretation of the findings and critically revised the manuscript. NP designed the study, supervised the writing of the manuscript, contributed to the interpretation of the findings and critically revised the manuscript. All authors contributed to the article and approved the submitted version.

15. Vendola K, Zhou J, Wang J, Bondy CA. Androgens Promote Insulin-Like Growth Factor-I and Insulin-Like Growth Factor-I Receptor Gene Expression in the Primate Ovary. Hum Reprod (1999) 14(9):2328-32. doi: 10.1093/ humrep/14.9.2328

16. Yang JL, Zhang CP, Li L, Huang L, Ji SY, Lu CL, et al. Testosterone Induces Redistribution of Forkhead Box-3a and Down-Regulation of Growth and Differentiation Factor 9 Messenger Ribonucleic Acid Expression At Early Stage of Mouse Folliculogenesis. Endocrinology (2010) 151(2):774-82. doi: 10.1210/en.2009-0751

17. Narkwichean A, Jayaprakasan K, Maalouf WE, Hernandez-Medrano JH, Pincott-Allen C, Campbell BK. Effects of Dehydroepiandrosterone on in Vivo Ovine Follicular Development. Hum Reprod (2014) 29(1):146-54. doi: 10.1093/humrep/det408

18. Laird M, Thomson K, Fenwick M, Mora J, Franks S, Hardy K. Androgen Stimulates Growth of Mouse Preantral Follicles in Vitro: Interaction With Follicle-Stimulating Hormone and With Growth Factors of the Tgf $\beta$ Super Family. Endocrinology (2017) 158(4):920-35. doi: 10.1210/en.2016-1538

19. Fujibe Y, Baba T, Nagao S, Adachi S, Ikeda K, Morishita M, et al. Androgen Potentiates the Expression of FSH Receptor and Supports Preantral Follicle Development in Mice. J Ovarian Res (2019) 12(1):1-8. doi: 10.1186/s13048019-0505-5

20. Weil S, Vendola K, Zhou J, Bondy CA. Androgen and Follicle-Stimulating Hormone Interactions in Primate Ovarian Follicle Development. J Clin Endocrinol Metab (1999) 84(8):2951-6. doi: 10.1210/jcem.84.8.5929

21. Sen A, Hammes SR. Granulosa Cell-Specific Androgen Receptors are Critical Regulators of Ovarian Development and Function. Mol Endocrinol (2010) 24 (7):1393-403. doi: 10.1210/me.2010-0006

22. Sen A, Prizant H, Light A, Biswas A, Hayes E, Lee HJ, et al. Androgens Regulate Ovarian Follicular Development by Increasing Follicle Stimulating Hormone Receptor and Microrna-125b Expression. Proc Natl Acad Sci USA (2014) 111(8):3008-13. doi: 10.1073/pnas.1318978111

23. Cárdenas H, Herrick JR, Pope WF. Increased Ovulation Rate in Gilts Treated With Dihydrotestosterone. Reproduction (2002) 123(4):527-33. doi: 10.1530/ reprod/123.4.527

24. Gill A, Jamnongjit M, Hammes SR. Androgens Promote Maturation and Signaling in Mouse Oocytes Independent of Transcription: A Release of Inhibition Model for Mammalian Oocyte Meiosis. Mol Endocrinol (2004) 18 (1):97-104. doi: 10.1210/me.2003-0326

25. Romero S, Smitz J. Exposing Cultured Mouse Ovarian Follicles Under Increased Gonadotropin Tonus to Aromatizable Androgens Influences the Steroid Balance and Reduces Oocyte Meiotic Capacity. Endocrine (2010) 38 (2):243-53. doi: 10.1007/s12020-010-9380-y

26. Hu YC, Wang PH, Yeh S, Wang RS, Xie C, Xu Q, et al. Subfertility and Defective Folliculogenesis in Female Mice Lacking Androgen Receptor. Proc Natl Acad Sci USA (2004) 101(31):11209-14. doi: 10.1073/pnas.0404372101

27. Walters KA, Allan CM, Jimenez M, Lim PR, Davey RA, Zajac JD, et al. Female Mice Haploinsufficient for an Inactivated Androgen Receptor (AR) Exhibit Age-Dependent Defects That Resemble the AR Null Phenotype of Dysfunctional Late Follicle Development, Ovulation, and Fertility. Endocrinology (2007) 148(8):3674-84. doi: 10.1210/en.2007-0248

28. Walters KA, Edwards MC, Tesic D, Caldwell ASL, Jimenez M, Smith JT, et al. The Role of Central Androgen Receptor Actions in Regulating the 
Hypothalamic-Pituitary-Ovarian Axis. Neuroendocrinology (2018) 106 (4):389-400. doi: 10.1159/000487762

29. Massin N, Cedrin-Durnerin I, Coussieu C, Galey-Fontaine J, Wolf JP, Hugues JN. Effects of Transdermal Testosterone Application on the Ovarian Response to FSH in Poor Responders Undergoing Assisted Reproduction Technique - a Prospective, Randomized, Double-Blind Study. Hum Reprod (2006) 21 (5):1204-11. doi: 10.1093/humrep/dei481

30. Fábregues F, Peñarrubia J, Creus M, Manau D, Casals G, Carmona F, et al. Transdermal Testosterone May Improve Ovarian Response to Gonadotrophins in Low-Responder IVF Patients: A Randomized, Clinical Trial. Hum Reprod (2009) 24(2):349-59. doi: 10.1093/humrep/den428

31. Kim CH, Howles CM, Lee HA. The Effect of Transdermal Testosterone Gel Pretreatment on Controlled Ovarian Stimulation and IVF Outcome in Low Responders. Fertil Steril (2011) 95(2):679-83. doi: 10.1016/j.fertnstert. 2010.07.1077

32. Kim C-H, Ahn J-W, Moon J-W, Kim S-H, Chae H-D, Kang B-M. Ovarian Features After 2 Weeks, 3 Weeks and 4 Weeks Transdermal Testosterone Gel Treatment and Their Associated Effect on IVF Outcomes in Poor Responders. Dev Reprod (2014) 18(3):145-52. doi: 10.12717/ DR.2014.18.3.145

33. Marzal Escriva A, Diaz-Garcia C, Monterde M, Rubio JM, Pellicer A. Antral Follicle Priming Before Intracytoplasmic Sperm Injection in Previously Diagnosed Low Responders: A Randomized Controlled Trial (FOLLPRIM). J Clin Endocrinol Metab (2015) 100(7):2597-605. doi: 10.1210/jc.2015-1194

34. Bosdou JK, Venetis CA, Dafopoulos K, Zepiridis L, Chatzimeletiou K, Anifandis G, et al. Transdermal Testosterone Pretreatment in Poor Responders Undergoing ICSI: A Randomized Clinical Trial. Hum Reprod (2016) 31(5):977-85. doi: 10.1093/humrep/dew028

35. Saharkhiz N, Zademodares S, Salehpour S, Hosseini S, Nazari L, Tehrani H. The Effect of Testosterone Gel on Fertility Outcomes in Women With a Poor Response in in Vitro Fertilization Cycles: A Pilot Randomized Clinical Trial. J Res Med Sci (2018) 23:3. doi: 10.4103/jrms.JRMS_864_17

36. Wiser A, Gonen O, Ghetler Y, Shavit T, Berkovitz A, Shulman A. Addition of Dehydroepiandrosterone (DHEA) for Poor-Responder Patients Before and During IVF Treatment Improves the Pregnancy Rate: A Randomized Prospective Study. Hum Reprod (2010) 25(10):2496-500. doi: 10.1093/ humrep/deq220

37. Artini PG, Simi G, Ruggiero M, Pinelli S, Di Berardino OM, Papini F, et al. DHEA Supplementation Improves Follicular Microenviroment in Poor Responder Patients. Gynecol Endocrinol (2012) 28(9):669-73. doi: 10.3109/ 09513590.2012 .705386

38. Moawad A, Shaeer M. Long-Term Androgen Priming by Use of Dehydroepiandrosterone (DHEA) Improves IVF Outcome in PoorResponder Patients. a Randomized Controlled Study. Middle East Fertil Soc $J$ (2012) 17(4):268-74. doi: 10.1016/j.mefs.2012.11.002

39. Yeung TWY, Li RHW, Lee VCY, Ho PC, Ng EHY. A Randomized DoubleBlinded Placebo-Controlled Trial on the Effect of Dehydroepiandrosterone for 16 Weeks on Ovarian Response Markers in Women With Primary Ovarian Insufficiency. J Clin Endocrinol Metab (2013) 98(1):380-8. doi: 10.1210/ jc.2012-3071

40. Yeung TWY, Chai J, Li RHW, Lee VCY, Ho PC, Ng EHY. A Randomized, Controlled, Pilot Trial on the Effect of Dehydroepiandrosterone on Ovarian Response Markers, Ovarian Response, and in Vitro Fertilization Outcomes in Poor Responders. Fertil Steril (2014) 102(1):4-7. doi: 10.1016/ j.fertnstert.2014.03.044

41. Kara M, Aydin T, Aran T, Turktekin N, Ozdemir B. Does Dehydroepiandrosterone Supplementation Really Affect IVF-ICSI Outcome in Women With Poor Ovarian Reserve? Eur J Obstet Gynecol Reprod Biol (2014) 173(1):63-5. doi: 10.1016/ j.ejogrb.2013.11.008

42. Zhang HH, Xu PY, Wu J, Zou WW, Xu XM, Cao XY, et al. Dehydroepiandrosterone Improves Follicular Fluid Bone Morphogenetic Protein-15 and Accumulated Embryo Score of Infertility Patients With Diminished Ovarian Reserve Undergoing in Vitro Fertilization: A Randomized Controlled Trial. J Ovarian Res (2014) 7:93. doi: 10.1186/s13048-014-0093-3

43. Kotb MMM, Hassan AGMA, AwadAllah AMA. Does Dehydroepiandrosterone Improve Pregnancy Rate in Women Undergoing IVF/ICSI With Expected Poor Ovarian Response According to the Bologna Criteria? a Randomized Controlled
Trial. Eur J Obstet Gynecol Reprod Biol (2016) 200:11-5. doi: 10.1016/ j.ejogrb.2016.02.009

44. Agarwal R, Shruthi R, Radhakrishnan G, Singh A. Evaluation of Dehydroepiandrosterone Supplementation on Diminished Ovarian Reserve: A Randomized, Double-Blinded, Placebo-Controlled Study. J Obstet Gynecol India (2017) 67(2):137-42. doi: 10.1007/s13224-016-0941-8

45. Narkwichean A, Maalouf W, Baumgarten M, Polanski L, Raine-Fenning N, Campbell B, et al. Efficacy of Dehydroepiandrosterone (DHEA) to Overcome the Effect of Ovarian Ageing (DITTO): A Proof of Principle Double Blinded Randomized Placebo Controlled Trial. Eur J Obstet Gynecol Reprod Biol (2017) 218:39-48. doi: 10.1016/j.ejogrb.2017.09.006

46. Elprince M, Kishk EA, Metawie OM, Albiely MM. Ovarian Stimulation After Dehydroepiandrosterone Supplementation in Poor Ovarian Reserve: A Randomized Clinical Trial. Arch Gynecol Obstet (2020) 302(2):529-34. doi: 10.1007/s00404-020-05603-5

47. Balasch J, Fábregues F, Peñarrubia J, Carmona F, Casamitjana R, Creus M, et al. Pretreatment With Transdermal Testosterone May Improve Ovarian Response to Gonadotrophins in Poor-Responder IVF Patients With Normal Basal Concentrations of FSH. Hum Reprod (2006) 21(7):1884-93. doi: 10.1093/humrep/del052

48. Mitri F, Behan LA, Murphy CA, Hershko-Klement A, Casper RF, Bentov Y. Microdose Flare Protocol With Interrupted Follicle Stimulating Hormone and Added Androgen for Poor Responders - an Observational Pilot Study. Fertil Steril (2016) 105(1):100-105.e6. doi: 10.1016/j.fertnstert.2015.09.038

49. Doan HT, Quan LH, Nguyen TT. The Effectiveness of Transdermal Testosterone Gel 1\% (Androgel) for Poor Responders Undergoing in Vitro Fertilization. Gynecol Endocrinol (2017) 33(12):977-9. doi: 10.1080/ 09513590.2017 .1332586

50. Fàbregues F, Solernou R, Ferreri J, Guimerá M, Peralta S, Casals G, et al. Comparison of Gnrh Agonist Versus Luteal Estradiol Gnrh Antagonist Protocol Using Transdermal Testosterone in Poor Responders. J Bras Reprod Assist (2019) 23(2):130-6. doi: 10.5935/1518-0557.20180090

51. Casson PR, Lindsay MS, Pisarska MD, Carson SA, Buster JE. Dehydroepiandrosterone Supplementation Augments Ovarian Stimulation in Poor Responders: A Case Series. Hum Reprod (2000) 15(10):2129-32. doi: 10.1093/humrep/15.10.2129

52. Barad DH, Gleicher N. Increased Oocyte Production After Treatment With Dehydroepiandrosterone. Fertil Steril (2005) 84(3):756.e1-3. doi: 10.1016/ j.fertnstert.2005.02.049

53. Barad D, Gleicher N. Effect of Dehydroepiandrosterone on Oocyte and Embryo Yields, Embryo Grade and Cell Number in IVF. Hum Reprod (2006) 21(11):2845-9. doi: 10.1093/humrep/del254

54. Barad D, Brill H, Gleicher N. Update on the Use of Dehydroepiandrosterone Supplementation Among Women With Diminished Ovarian Function. J Assist Reprod Genet (2007) 24(12):629-34. doi: 10.1007/s10815-0079178-x

55. Mamas L, Mamas E. Premature Ovarian Failure and Dehydroepiandrosterone. Fertil Steril (2009) 91(2):644-6. doi: 10.1016/j.fertnstert.2007.11.055

56. Mamas L, Mamas E. Dehydroepiandrosterone Supplementation in Assisted Reproduction: Rationale and Results. Curr Opin Obstet Gynecol (2009) 21 (4):306-8. doi: 10.1097/GCO.0b013e32832e0785

57. Sönmezer M, Özmen B, Çil AP, Özkavukçu S, Taşçi T, Olmuş H, et al. Dehydroepiandrosterone Supplementation Improves Ovarian Response and Cycle Outcome in Poor Responders. Reprod BioMed Online (2009) 19(4):50813. doi: 10.1016/j.rbmo.2009.06.006

58. Gleicher N, Ryan E, Weghofer A, Blanco-Mejia S, Barad DH. Miscarriage Rates After Dehydroepiandrosterone (DHEA) Supplementation in Women With Diminished Ovarian Reserve: A Case Control Study. Reprod Biol Endocrinol (2009) 7:108. doi: 10.1186/1477-7827-7-108

59. Gleicher N, Weghofer A, Barad DH. Dehydroepiandrosterone (DHEA) Reduces Embryo Aneuploidy: Direct Evidence From Preimplantation Genetic Screening (PGS). Reprod Biol Endocrinol (2010) 8:1-5. doi: 10.1186/1477-7827-8-140

60. Gleicher N, Weghofer A, Barad DH. Improvement in Diminished Ovarian Reserve After Dehydroepiandrosterone Supplementation. Reprod BioMed Online (2010) 21(3):360-5. doi: 10.1016/j.rbmo.2010.04.006

61. Weissman A, Horowitz E, Ravhon A, Golan A, Levran D. Dehydroepiandrosterone Supplementation Increases Baseline Follicular 
Phase Progesterone Levels. Gynecol Endocrinol (2011) 27(12):1014-7. doi: 10.3109/09513590.2011.569611

62. Fusi FM, Ferrario M, Bosisio C, Arnoldi M, Zanga L. DHEA Supplementation Positively Affects Spontaneous Pregnancies in Women With Diminished Ovarian Function. Gynecol Endocrinol (2013) 29(10):940-3. doi: 10.3109/ 09513590.2013.819087

63. Hyman JH, Margalioth EJ, Rabinowitz R, Tsafrir A, Gal M, Alerhand S, et al. DHEA Supplementation May Improve IVF Outcome in Poor Responders: A Proposed Mechanism. Eur J Obstet Gynecol Reprod Biol (2013) 168(1):49-53. doi: 10.1016/j.ejogrb.2012.12.017

64. Singh N, Zangmo R, Kumar S, Roy KK, Sharma JB, Malhotra N, et al. A Prospective Study on Role of Dehydroepiandrosterone (DHEA) on Improving the Ovarian Reserve Markers in Infertile Patients With Poor Ovarian Reserve. Gynecol Endocrinol (2013) 29(11):989-92. doi: 10.3109/09513590.2013. 824957

65. Yilmaz N, Uygur D, Inal H, Gorkem U, Cicek N, Mollamahmutoglu L. Dehydroepiandrosterone Supplementation Improves Predictive Markers for Diminished Ovarian Reserve: Serum AMH, Inhibin B and Antral Follicle Count. Eur J Obstet Gynecol Reprod Biol (2013) 169(2):257-60. doi: 10.1016/ j.ejogrb.2013.04.003

66. Jirge PR, Chougule SM, Gavali VG, Bhomkar DA. Impact of Dehydroepiandrosterone on Clinical Outcome in Poor Responders: A Pilot Study in Women Undergoing in Vitro Fertilization, Using Bologna Criteria. J Hum Reprod Sci (2014) 7(3):175-80. doi: 10.4103/09741208.142477

67. Xu B, Li Z, Yue J, Jin L, Li Y, Ai J, et al. Effect of Dehydroepiandrosterone Administration in Patients With Poor Ovarian Response According to the Bologna Criteria. PloS One (2014) 9(6):1-5. doi: 10.1371/journal.pone. 0099858

68. Zangmo R, Singh N, Kumar S, Vanamail P, Tiwari A. Role of Dehydroepiandrosterone in Improving Oocyte and Embryo Quality in IVF Cycles. Reprod BioMed Online (2014) 28(6):743-7. doi: 10.1016/j. rbmo.2014.01.019

69. Tsui KH, Te LL, Chang R, Huang BS, Cheng JT, Wang PH. Effects of Dehydroepiandrosterone Supplementation on Women With Poor Ovarian Response: A Preliminary Report and Review. Taiwan J Obstet Gynecol (2015) 54(2):131-6. doi: 10.1016/j.tjog.2014.07.007

70. Vlahos N, Papalouka M, Triantafyllidou O, Vlachos A, Vakas P, Grimbizis G, et al. Dehydroepiandrosterone Administration Before IVF in Poor Responders: A Prospective Cohort Study. Reprod BioMed Online (2015) 30 (2):191-6. doi: 10.1016/j.rbmo.2014.10.005

71. Hu Q, Hong L, Nie M, Wang Q, Fang Y, Dai Y, et al. The Effect of Dehydroepiandrosterone Supplementation on Ovarian Response is Associated With Androgen Receptor in Diminished Ovarian Reserve Women. J Ovarian Res (2017) 10(1):1-10. doi: 10.1186/s13048-017-0326-3

72. Chern CU, Tsui KH, Vitale SG, Chen SN, Wang PH, Cianci A, et al. Dehydroepiandrosterone (DHEA) Supplementation Improves in Vitro Fertilization Outcomes of Poor Ovarian Responders, Especially in Women With Low Serum Concentration of DHEA-S: A Retrospective Cohort Study 11 Medical and Health Sciences 1114 Paediatrics and. Reprod Biol Endocrinol (2018) 16(1):1-9. doi: 10.1186/s12958-018-0409-z

73. Al-Turki HA. Dehydroepiandrosterone Supplementation in Women Undergoing Assisted Reproductive Technology With Poor Ovarian Response. a Prospective Case-Control Study. J Int Med Res (2018) 46 (1):143-9. doi: 10.1177/0300060517720005

74. Wong QHY, Yeung TWY, Yung SSF, Ko JKY, Li HWR, Ng EHY. The Effect of 12-Month Dehydroepiandrosterone Supplementation on the Menstrual Pattern, Ovarian Reserve Markers, and Safety Profile in Women With Premature Ovarian Insufficiency. J Assist Reprod Genet (2018) 35(5):857-62. doi: $10.1007 / \mathrm{s} 10815-018-1152-2$

75. Chen SN, Tsui KH, Wang PH, Chern CU, Wen ZH, Lin L. Dehydroepiandrosterone Supplementation Improves the Outcomes of in Vitro Fertilization Cycles in Older Patients With Diminished Ovarian Reserve. Front Endocrinol (Lausanne) (2019) 10(November):1-7. doi: 10.3389/fendo.2019.00800

76. Ozcil MD. Dehydroepiandrosterone Supplementation Improves Ovarian Reserve and Pregnancy Rates in Poor Responders. Eur Rev Med Pharmacol Sci (2020) 24(17):9104-11. doi: 10.26355/eurrev_202009_22856
77. Urman B, Yakin K. DHEA for Poor Responders: Can Treatment Be Justified in the Absence of Evidence? Reprod BioMed Online (2012) 25(2):103-7. doi: 10.1016/j.rbmo.2012.05.009

78. Webb S, Geoghegan T, Prough R, Miller K. The Biological Actions of Dehydroepiandrosterone Involves Multiple Receptors. Drug Metab Rev (2006) 38:89-116. doi: 10.1080/03602530600569877

79. Singh AB, Lee ML, Sinha-Hikim I, Kushnir M, Meikle W, Rockwood A, et al. Pharmacokinetics of a Testosterone Gel in Healthy Postmenopausal Women. J Clin Endocrinol Metab (2006) 91(1):136-44. doi: 10.1210/jc.2005-1640

80. Fooladi E, Reuter SE, Bell RJ, Robinson PJ, Davis SR. Pharmacokinetics of a Transdermal Testosterone Cream in Healthy Postmenopausal Women. Menopause (2015) 22(1):44-9. doi: 10.1097/GME.0000000000000259

81. Gougeon A. Dynamics of Follicular Growth in the Human : A Model From Preliminary Results. (1986) 1(2):81-7. doi: 10.1093/oxfordjournals.humrep. a136365

82. Poseidon Group, Alviggi C, Andersen CY, Buehler K, Conforti A, De Placido G, et al. A New More Detailed Stratification of Low Responders to Ovarian Stimulation: From a Poor Ovarian Response to a Low Prognosis Concept. Fertil Steril (2016) 105(6):1452-3. doi: 10.1016/j.fertnstert.2016.02.005

83. Esteves SC, Alviggi C, Humaidan P, Fischer R, Andersen CY, Conforti A, et al. The POSEIDON Criteria and Its Measure of Success Through the Eyes of Clinicians and Embryologists. Front Endocrinol (Lausanne) (2019) 10 (November):1-8. doi: 10.3389/fendo.2019.00814

84. Narkwichean A, Maalouf W, Campbell BK, Jayaprakasan K. Efficacy of Dehydroepiandrosterone to Improve Ovarian Response in Women With Diminished Ovarian Reserve: A Meta-Analysis. Reprod Biol Endocrinol (2013) 11:1-8. doi: 10.1186/1477-7827-11-44

85. Li J, Yuan H, Chen Y, Wu H, Wu H, Li L. A Meta-Analysis of Dehydroepiandrosterone Supplementation Among Women With Diminished Ovarian Reserve Undergoing in Vitro Fertilization or Intracytoplasmic Sperm Injection. Int J Gynecol Obstet (2015) 131(3):2405. doi: 10.1016/j.ijgo.2015.06.028

86. Qin JC, Fan L, Qin AP. The Effect of Dehydroepiandrosterone (DHEA) Supplementation on Women With Diminished Ovarian Reserve (DOR) in IVF Cycle: Evidence From a Meta-Analysis. J Gynecol Obstet Hum Reprod (2016) 46(1):1-7. doi: 10.1016/j.jgyn.2016.01.002

87. Liu Y, Hu L, Fan L, Wang F. Efficacy of Dehydroepiandrosterone (DHEA) Supplementation for in Vitro Fertilization and Embryo Transfer Cycles: A Systematic Review and Meta-Analysis. Gynecol Endocrinol (2017) 34(3):17883. doi: 10.1080/09513590.2017.1391202

88. Schwarze JE, Canales J, Crosby J, Ortega-Hrepich C, Villa S, Pommer R. DHEA Use to Improve Likelihood of IVF/ICSI Success in Patients With Diminished Ovarian Reserve: A Systematic Review and Meta-Analysis. J Bras Reprod Assist (2018) 22(4):369-74. doi: 10.5935/1518-0557.20180046

89. Xu L, Hu C, Liu Q, Li Y. The Effect of Dehydroepiandrosterone (DHEA) Supplementation on IVF or ICSI: A Meta-Analysis of Randomized Controlled Trials. Geburtshilfe Frauenheilkd (2019) 79(7):705-12. doi: 10.1055/a-08823791

90. González-Comadran M, Durán M, Solà I, Fábregues F, Carreras R, Checa MA. Effects of Transdermal Testosterone in Poor Responders Undergoing IVF: Systematic Review and Meta-Analysis. Reprod BioMed Online (2012) 25 (5):450-9. doi: 10.1016/j.rbmo.2012.07.011

91. Luo S, Li SW, Li XH, Qin L, Jin S. Effect of Pretreatment With Transdermal Testosterone on Poor Ovarian Responders Undergoing IVF/ICSI: A MetaAnalysis. Exp Ther Med (2014) 8(1):187-94. doi: 10.3892/etm.2014.1683

92. Noventa M, Vitagliano A, Andrisani A, Blaganje M, Viganò P, Papaelo E, et al. Testosterone Therapy for Women With Poor Ovarian Response Undergoing IVF: A Meta-Analysis of Randomized Controlled Trials. J Assist Reprod Genet (2019) 36(4):673-83. doi: 10.1007/s10815-018-1383-2

93. Sunkara SK, Pundir J, Khalaf Y. Effect of Androgen Supplementation or Modulation on Ovarian Stimulation Outcome in Poor Responders: A MetaAnalysis. Reprod BioMed Online (2011) 22(6):545-55. doi: 10.1016/ j.rbmo.2011.01.015

94. Bosdou JK, Venetis CA, Kolibianakis EM, Toulis KA, Goulis DG, Zepiridis L, et al. The Use of Androgens or Androgen-Modulating Agents in Poor Responders Undergoing in Vitro Fertilization: A Systematic Review and Meta-Analysis. Hum Reprod Update (2012) 18(2):127-45. doi: 10.1093/ humupd/dmr051 
95. Nagels H, Rishworth J, Siristatidis C, Kroon B. Androgens (Dehydroepiandrosterone or Testosterone) for Women Undergoing Assisted Reproduction. Cochrane Database Syst Rev (2015) (11):CD009749. doi: 10.1002/14651858.CD009749.pub2

96. Zhang Y, Zhang C, Shu J, Guo J, Chang HM, Leung PCK, et al. Adjuvant Treatment Strategies in Ovarian Stimulation for Poor Responders Undergoing IVF: A Systematic Review and Network MetaAnalysis. Hum Reprod Update (2020) 26(2):247-63. doi: 10.1093/humupd/ dmz046

97. Baerwald AR, Adams GP, Pierson RA. Ovarian Antral Folliculogenesis During the Human Menstrual Cycle: A Review. Hum Reprod Update (2012) 18(1):73-91. doi: 10.1093/humupd/dmr039
Conflict of Interest: NP is the principal investigator of the T-TRANSPORT trial.

The remaining authors declare that the research was conducted in the absence of any commercial or financial relationships that could be construed as a potential conflict of interest.

Copyright (C) 2021 Neves, Montoya-Botero and Polyzos. This is an open-access article distributed under the terms of the Creative Commons Attribution License (CC BY).

The use, distribution or reproduction in other forums is permitted, provided the original author(s) and the copyright owner(s) are credited and that the original publication in this journal is cited, in accordance with accepted academic practice. No use, distribution or reproduction is permitted which does not comply with these terms. 